\title{
State-owned enterprises in China Reform dynamics and impacts
}

\section{Xiao Geng, Xiuke Yang and Anna Janus}

\section{Introduction}

Large-scale SOE reform in China has been going on since 1978. In spite of the Chinese Government's efforts towards privatisation and its commitment to market-oriented development, SOEs remain a dominant part of the Chinese economy, especially among certain strategically important sectors, such as infrastructure construction, telecommunications, financial services, energy and raw materials. The question of how this apparent paradox can be resolved - and what the explanation might imply for our understanding of China-is the main focus for this chapter. Many questions arise in this context: should the Chinese Government continue its trend of privatising SOEs or should it continue to keep control of the largest and most important SOEs? Is there a set of implicit objectives in government policies that can explain China's SOE reform dynamics in the past and predict future trends?

SOE reform in China has been unique in many ways. Unlike the abrupt approach to privatisation adopted in Russia, which was followed by a collapse of the economies in all former Soviet Union partner countries in the last decade of the twentieth century, the more gradual approach taken in China has entailed a steady expansion of SOE assets and profits, as well as an accumulation of power and influence among SOEs. Unlike in India, which has to cope with high urban unemployment and poor industrial infrastructure, in China, the privatisation of SOEs has coincided with large-scale improvement of infrastructure and still relatively low urban unemployment.

This chapter reviews the relative performance of large and mediumsized enterprises during the reform period in a comprehensive and systematic way in order to reveal possible underlying patterns and trends. For this purpose, we have used three sets of data: sector-level annual 
survey data for China's large and medium-sized industrial enterprises from 1995 to 2005, collected by the National Bureau of Statistics; firmlevel survey data for China's top-500 enterprises, published by the China Enterprise Confederation; and the Fortune Global 500 data published by Fortune Magazine. For our analysis, we have used the novel approach of grouping SOEs by sector into two categories: the competitive and the strategic markets. This distinction was made based on the specific characteristics of the industry sectors. The competitive market contains sectors that relate to the manufacturing of consumer products. Sectors in this market have undergone intensive privatisation. The strategic market contains sectors such as infrastructure construction, financial services, energy and raw materials, where there are still government-imposed market entry barriers. Many government documents and research papers have cited such a distinction when discussing industrial policy, although there has been no official classification of which industries belong to competitive markets and which to strategic markets. The distinction we make in this chapter helps us unveil an implicit objective function behind the facts of SOE transformation in China. The analytical framework in this chapter also highlights the impacts of reforms on enterprise performance as well as on the Chinese economy and society. The results of this study show a comprehensive picture of SOE transformation and provide a useful foundation for consideration of future reforms.

We begin with a review of the advancement of SOE transformation since the beginning of the reforms and an assessment of the current state of SOEs in China. We then explore the characteristic dynamics of SOE transformation in the main part of our chapter. Possible policy implications are then outlined.

\section{Progress of SOE reforms in China}

\section{Background of SOE reform}

Under heavy influence from the Soviet Union, China gave birth to the SOEs about 50 years ago after the establishment of the People's Republic of China and the socialist industrialisation that came soon after. In less than 10 years, China nationalised virtually all private industrial enterprises during the 1950s. Before 1978 - the year that marked the beginning of market-oriented transformation - China operated its SOEs under a centrally planned economy. Since 1978, Chinese authorities have initiated 
intensive reforms and privatisation of SOEs. At the macro level, the SOE reforms can be seen as a strategic adjustment of the nationalised and centralised economy towards a more market-oriented economy; at the micro level, the reforms are intended to transform the Chinese SOEs into modern corporations. Specifically, SOE reforms fall into three successive phases.

The first phase, from 1978 to 1984, concentrated on increasing managerial autonomy in order to motivate the Chinese SOEs to pursue profit and growth. By loosening its hold on the planned economy, the Chinese Government to some degree began to weaken the link between the State and enterprises. Managers were essentially allowed to sell surplus production at market prices for a profit, once the planned quotas for production were met. The most important innovations during this period were the delegation of managerial autonomy from government bureaucracy to enterprise managers and the introduction of a dual-price system (the existing planned price for within-the-quota output and the new market price for above-the-quota output).

The second phase, from 1985 to 1993, focused on separating company ownership and management by introducing a 'contract responsibility' system. Managers signed a contract with the relevant government agencies and became the legal representatives of the SOE, consequently being held responsible for the company's profits and losses. The idea of reform during this period was to transform SOEs into truly independent economic entities that were responsible for their own profits and losses, as well as to establish independent legal entities that shared certain rights and obligations. The result was that the management teams tended to pursue short-term interests rather than long-term profitable growth because they had the rights only to operate SOEs but no clear property rights. The main problem of the 'responsibility system' is that the managers can easily share profits with the government and employees but are not practically capable of assuming losses and liabilities that might follow from their managerial decisions, since they do not own any significant amount of assets or property.

The third phase, starting from 1993 and continuing into the present, emphasised transforming SOEs into modern corporations. The main elements of reform during this period include the policies of 'grasping the large and letting go the small', severing the link between the State and labour, as well as changing the State's position towards shareholders 
under mixed ownership (state and non-state ownership). During this period, privatisation took place on a large scale, notably among small SOEs. Some of the largest SOEs are even being listed on the young Chinese stock markets and the Hong Kong Stock Exchange, usually with the State still holding about two-thirds of the shares in the listed companies.

\section{Current state of Chinese SOEs}

Even after more than two decades of market-oriented reforms, SOEs still play a prominent role in the Chinese economy. To examine the most relevant trends, our focus here will be on SOEs among large and mediumsized enterprises in China.

In 2005, there were 3999 SOEs among all large and medium-sized industrial enterprises (25 per cent of the total), centralising assets of RMB6.09 trillion (58 per cent of the total) and generating a total profit of RMB268 billion (48 per cent of the total) (Table 9.1).

\section{Table 9.1 Structure and performance of SOEs in large and medium-} sized industrial enterprises, 2005

\begin{tabular}{lcccc}
\hline Ownership & No. SOEs & Assets (RMB billion) & Profit (RMB billion) & ROA (\%) \\
\hline State & 3999 & 6090 & 268 & 4.40 \\
Collective & 1331 & 343 & 23 & 6.62 \\
Private & 5584 & 1110 & 68 & 6.13 \\
Foreign & 5272 & 2880 & 203 & 7.05 \\
Total & 16186 & 10423 & 562 & 5.39 \\
\hline
\end{tabular}

$\mathrm{ROA}=$ return on assets

Source: National Bureau of Statistics (NBS) 2005, China Statistical Yearbook 2005, China Statistics Press, Beijing.

Table 9.2 Structure and performance of top-500 Chinese enterprises in 2007, by ownership (per cent)

\begin{tabular}{lcccccc}
\hline Ownership & No. SOEs & Assets & Profit & Employees & Taxes & ROA \\
\hline State & 69.8 & 93.6 & 87.9 & 89.3 & 92.7 & 1.4 \\
Collective & 5.8 & 4.2 & 2.2 & 2.4 & 1.7 & 0.8 \\
Private & 17.8 & 1.7 & 7.1 & 7.0 & 3.9 & 6.1 \\
Foreign & 6.6 & 0.5 & 2.8 & 1.3 & 1.7 & 8.5 \\
\hline
\end{tabular}

$\mathrm{ROA}=$ return on assets

Source: A Report on the Development of China's Enterprises 2007, Enterprise Management Publishing House, Beijing, Chapter 12, p. 88. 
In 2007, of the top-500 Chinese enterprises, an astounding 69.8 per cent were SOEs, accounting for 94 per cent of asset value and creating 88 per cent of the total profit (Table 9.2). SOEs are not only economically dominant, they are still socially relevant too, employing 89.3 per cent of the workforce and contributing 92.7 per cent of overall taxes.

In 2007, of the top-500 Chinese manufacturing enterprises, almost 50 per cent were SOEs, creating 61 per cent of the total profit (Table 9.3).

Table 9.3 Structure and performance of top-500 Chinese manufacturing enterprises in 2007, by ownership (per cent)

\begin{tabular}{lccc}
\hline Ownership & No. SOEs & Profit & ROA \\
\hline State & 49.8 & 61.1 & 3.2 \\
Collective & 7.8 & 7.8 & 6.2 \\
Private & 29.4 & 21.4 & 6.4 \\
Foreign & 13.0 & 9.7 & 7.9 \\
\hline
\end{tabular}

$\mathrm{ROA}=$ return on assets

Source: A Report on the Development of China's Enterprises 2007, Enterprise Management Publishing House, Beijing, Chapter 13, p. 126.

In 2007, of the top-500 Chinese service-sector enterprises, SOEs were even more dominant, accounting for 94 per cent of assets, 92 per cent of profit and 61 per cent of the number of firms (Table 9.4).

Table 9.4 Structure and performance of top-500 Chinese enterprises in the service industry in 2007 , by ownership (per cent)

\begin{tabular}{lcccc}
\hline Ownership & No. SOEs & Assets & Profit & ROA \\
\hline State & 61.4 & 93.6 & 92.4 & 0.8 \\
Collective & 11.4 & 5.4 & 1.1 & 0.2 \\
Private & 23.2 & 0.8 & 5.3 & 5.3 \\
Foreign & 4.0 & 0.1 & 1.2 & 8.3 \\
\hline
\end{tabular}

$\mathrm{ROA}=$ return on assets

Source: A Report on the Development of China's Enterprises 2007, Enterprise Management Publishing House, Beijing, Chapter 14, p. 137.

Meanwhile, Chinese SOEs are also becoming a globally noticeable force. In 2007, there were 22 Chinese SOEs listed in the Fortune Global 500 and China ranked sixth in the number of firms by country. The contributions of the 22 Chinese SOEs in the Fortune Global 500 include employment of 13 per cent of the workforce, 3.6 per cent of overall profit and 3.8 per cent of total revenue (Table 9.5). 
Table 9.5 Structure and performance of Fortune Global 500 in 2007, by country (per cent)

\begin{tabular}{lcccccc}
\hline Country & No. firms & Assets & Revenue & Profit & No. employees & ROA \\
\hline United States & 32.4 & 25.5 & 35.1 & 38.5 & 34.1 & 2.7 \\
Japan & 13.4 & 9.4 & 11.5 & 7.0 & 9.4 & 1.3 \\
France & 7.6 & 10.9 & 8.7 & 7.4 & 9.7 & 1.2 \\
Germany & 7.4 & 9.5 & 8.8 & 5.7 & 8.9 & 1.1 \\
Britain & 6.6 & 12.1 & 7.4 & 8.3 & 6.1 & 1.2 \\
China & 4.4 & 4.7 & 3.8 & 3.5 & 13.0 & 1.4 \\
\hline
\end{tabular}

$\mathrm{ROA}=$ return on assets

Source: 'Fortune Global 500', Fortune Magazine, 23 July 2007.

In addition, the Chinese SOEs accounted for three of the top-five largest employers in the world in 2006 (Table 9.6) and three of the top-five enterprises in Asia in terms of revenue (Table 9.7).

Table 9.6 Top-five enterprises in Asia in 2006, by revenue

\begin{tabular}{lcc}
\hline Company & Country & Revenue (\$million) \\
\hline Toyota Motors & Japan & 204746.4 \\
Sinopec & China & 131636 \\
China National Petroleum & China & 110520.2 \\
State Grid & China & 107185.5 \\
Honda Motors & Japan & 94790.5 \\
\hline
\end{tabular}

Source: 'Fortune Global 500', Fortune Magazine, 23 July 2007.

Table 9.7 Top-five biggest employers in the world, 2006

\begin{tabular}{lcc}
\hline Company & Country & No. employees \\
\hline Wal-Mart Stores & United States & 1900000 \\
State Grid & China & 1504000 \\
China National Petroleum & China & 1086966 \\
US Postal Service & United States & 796199 \\
Sinopec & China & 681900 \\
\hline
\end{tabular}

Source: 'Fortune Global 500', Fortune Magazine, 23 July 2007.

For the SOE reforms in the past 30 years, however, revenues and profits have consistently run ahead of deeper enterprise transformation such as improvement of operating efficiency and enhancement of industrial productivity. The return on assets (ROA) of Chinese SOEs in the top-500 Chinese enterprises was only 1.4 per cent in 2007-lagging far behind non-state enterprises (NSEs) in China, such as private-owned enterprises 
(6.08 per cent) and foreign-funded enterprises (8.48 per cent) (Table 9.2). As for return on equity (ROE), it is only 10.07 per cent for the heavily SOE-dominated top-500 Chinese enterprises-performing far worse than the Fortune Global 500 average of 16.13 per cent (Table 9.8).

\section{Table 9.8 Performance of top-500 Chinese and global companies} (per cent)

\begin{tabular}{lll}
\hline & ROA & ROE \\
\hline Top-500 Chinese enterprises & 1.82 & 10.07 \\
Fortune Global 500 companies & 1.79 & 16.13 \\
\hline
\end{tabular}

$\mathrm{ROA}=$ return on assets

$\mathrm{ROE}=$ return on equity

Sources: A Report on the Development of China's Enterprises 2007, Enterprise Management Publishing House, Beijing; 'Fortune Global 500', Fortune Magazine, 23 July 2007.

Clearly, apart from increasing revenues and profits, Chinese SOEs still show major deficiencies in regard to efficiency and productivity. As a major economic force in China, they are also quickly becoming more relevant on a global scale. There appears therefore to be a continuing need for reform and enhanced policies for SOEs in China. In order for China's economic transformation to be successful, we have to recognise accurately what is happening in the Chinese SOEs. For this purpose, this chapter attempts to shed some light on the underlying characteristics of SOE reform in China.

\section{The dynamics of SOE reform in China}

\section{Our analytical approach}

In order to highlight the special characteristics of SOE reform in China, this chapter uses sector-level annual survey data from China's large and medium-sized industrial enterprises during 1995-2005, which are collected at the firm level and maintained at the National Bureau of Statistics (NBS) in China. The sector-level data allow us to compare enterprise performance across ownership, industry and time. The NBS survey covers all of the large and medium-sized industrial enterprises in 38 sectors (Appendix 9.1). In addition to differentiating firms by ownership and by sector (as other studies have done), this chapter groups the 38 sectors into two overall categories: the strategic market and the competitive market (Appendices 9.2 and 9.3). The strategic market, including the sectors of 
infrastructure construction, energy and raw materials, has been providing critical infrastructure support for the Chinese national economy, whereas the competitive market, including sectors related to personal services and the manufacturing of consumer products, is essential to improving the living standards of the Chinese people. Such a distinction allows us to systematically interpret reform processes and to derive considerations and strategies for future SOE reform.

\section{Special characteristics of SOE reform in China}

The transformation of SOEs has been characterised on the one hand by a rapid decline in the number of SOEs and on the other hand by a steady accumulation and expansion of state-owned assets as well as profits in large and medium-sized industrial enterprises.

The number of Chinese SOEs in large and medium-sized industrial enterprises was 15107 in 1995 and diminished to 3999 in 2005-a loss of 73.5 per cent - and the number of all industrial SOEs fell from 118000 in 1995 to 27500 in 2005, a loss of 76.7 per cent (Table 9.9). The sharp decrease in the number of SOEs shows how dramatically privatisation has taken place in the course of reforms.

Table 9.9 The number of industrial SOEs in China, 1995-2005

\begin{tabular}{lcc}
\hline Year & $\begin{array}{c}\text { No. industrial SOEs } \\
\text { (all sizes) }\end{array}$ & $\begin{array}{c}\text { No. industrial SOEs } \\
\text { (large and medium-sized) }\end{array}$ \\
\hline 1995 & 118000 & 15107 \\
2000 & 53500 & 9144 \\
2005 & 27500 & 3999 \\
\hline
\end{tabular}

Sources: National Bureau of Statistics (NBS) 1995, China Statistical Yearbook 1995, China Statistics Press, Beijing; National Bureau of Statistics (NBS) 2000, China Statistical Yearbook 2000, China Statistics Press, Beijing; National Bureau of Statistics (NBS) 2005, China Statistical Yearbook 2005, China Statistics Press, Beijing.

The state-owned assets in large and medium-sized industrial enterprises, however, steadily accumulated from RMB3.89 trillion in 1995 to RMB6.09 trillion in 2005 (Table 9.10), with a compound annual growth rate of 4.6 per cent for 10 years. At the same time, the profit generated from large and medium-sized state-owned industrial enterprises also soared - from RMB70.8 billion in 1995 to RMB268 billion in 2005, with a compound annual growth rate as high as 14.2 per cent-indicating that the privatisation and transformation of SOEs during this period contributed to a dramatic increase in state-owned profits and assets, which enhanced the government's financial, political and social net asset value. 
Table 9.10 Assets and profits of SOEs in large and medium-sized industrial enterprises

\begin{tabular}{lccc}
\hline & & & \\
\hline Year & Assets (RMB billion) & Profit (RMB billion) & ROA (\%) \\
\hline 1995 & 3890 & 70.8 & 1.82 \\
2000 & 4640 & 87.4 & 1.88 \\
2005 & 6090 & 268 & 4.40 \\
\hline
\end{tabular}

$\mathrm{ROA}=$ return on assets

Sources: National Bureau of Statistics (NBS) 1995, China Statistical Yearbook 1995, China Statistics Press, Beijing; National Bureau of Statistics (NBS) 2000, China Statistical Yearbook 2000, China Statistics Press, Beijing; National Bureau of Statistics (NBS) 2005, China Statistical Yearbook 2005, China Statistics Press, Beijing.

Starting with these observations, we explore two key hypotheses about SOE reform in China.

\section{Hypothesis 1}

SOEs are more likely to be privatised when they are losing profit in the competitive market.

If we examine the competitive market and the strategic market separately (Table 9.11), we can see that the number of SOEs in the competitive market has diminished dramatically from 12128 in 1995 to 1975 in 2005 (a loss of 83.7 per cent). However, the amount of state-owned assets in the competitive market remained relatively stable (falling from RMB1819 billion in 1995 to RMB1423 billion in 2005).

\section{Table 9.11 The number and performance of SOEs in the competitive market}

\begin{tabular}{lcccc}
\hline & & & & \\
\hline Year & No. SOEs & Assets (RMB billion) & Profit (RMB billion) & ROA (\%) \\
\hline 1995 & 12128 & 1819 & 9 & 0.51 \\
2000 & 6872 & 1902 & 7 & 0.38 \\
2005 & 1975 & 1423 & 27 & 1.89 \\
\hline
\end{tabular}

$\mathrm{ROA}=$ return on assets

Sources: National Bureau of Statistics (NBS) 1995, China Statistical Yearbook 1995, China Statistics Press, Beijing; National Bureau of Statistics (NBS) 2000, China Statistical Yearbook 2000, China Statistics Press, Beijing; National Bureau of Statistics (NBS) 2005, China Statistical Yearbook 2005, China Statistics Press, Beijing.

At the same time, the change in the number of SOEs in the strategic market was less extreme - from 2979 in 1995 to 2024 in 1995 (a loss of only 32 per cent) - yet there was a remarkable increase in state-owned assets, from RMB1.99 trillion to RMB4.66 trillion (Table 9.12). 
Table 9.12 The number and performance of SOEs in the strategic market

\begin{tabular}{lcccc}
\hline Year & No. SOEs & Assets (RMB billion) & Profit (RMB billion) & ROA (\%) \\
\hline 1995 & 2979 & 1985 & 62 & 3.10 \\
\hline 2000 & 2272 & 2642 & 80 & 3.03 \\
\hline 2005 & 2024 & 4664 & 241 & 5.17 \\
\hline
\end{tabular}

$\mathrm{ROA}=$ return on assets

Sources: National Bureau of Statistics (NBS) 1995, China Statistical Yearbook 1995, China Statistics Press, Beijing; National Bureau of Statistics (NBS) 2000, China Statistical Yearbook 2000, China Statistics Press, Beijing; National Bureau of Statistics (NBS) 2005, China Statistical Yearbook 2005, China Statistics Press, Beijing.

Looking more closely at the competitive market (Table 9.11), it is striking to see that the ROA of SOEs was as low as 0.5 per cent in 1995, 0.4 per cent in 2000 and 1.9 per cent in 2005-lagging far behind the ROA achieved by SOEs in the strategic market, which was 3.1 per cent in 1995, 3.0 per cent in 2000 and 5.2 per cent in 2005 (Table 9.12). The ROA of SOEs in the competitive market was also significantly lower than the ROA of NSEs - 4.6 per cent in 1995, 6.26 per cent in 2000 and 7.04 per cent in 2005 (Table 9.14).

The above empirical evidence shows privatisation has been rather instrumental in the abandonment of less-profitable and less-efficient SOEs and thus reducing financial, social and political liabilities arising from loss-making SOEs.

\section{Hypothesis 2}

When SOEs are profitable in the strategic market, their sector's state monopoly is more likely to be maintained.

Looking more closely at the strategic market, the number of SOEs has remained relatively stable during the reform period, while the number of assets accumulated in the strategic market has soared remarkably. Moreover, the strategic market was also immensely profitable, with a rise in total profit from RMB61.5 billion in 1995 to RMB241.2 billion in 2005 (Table 9.12). Enterprises in the strategic market had an average ROA of 5.17 per cent in 2005 compared with 1.89 per cent in the competitive market. The government's strong grip on the strategic market is obvious from the proportion of state-owned assets to total assets in the respective sectors. In the strategic market, state-owned assets accounted for 56 per cent of total assets, while in the competitive market the number was only 15 per 
cent in 2005 (Table 9.13). The strategic market comprises various sectors in which SOEs still hold monopolies, such as infrastructure and energy, and it becomes evident from our analysis that SOEs in this market have been consistently maintained. From the view of the government, reforms of SOEs in the strategic market have led to an increase in profit and asset value and a strengthening of social and political assets.

\section{Table 9.13 Total assets in the strategic and competitive markets} in 2005 (RMB billion)

\begin{tabular}{lccc}
\hline & State-owned assets & Total assets & State-owned assets (\%) \\
\hline Total & 6086.7 & 17632.5 & 34.5 \\
\hline The strategic market & 4663.7 & 8338.9 & 55.9 \\
\hline The competitive market & 1423 & 9293.6 & 15.3 \\
\hline
\end{tabular}

Source: National Bureau of Statistics (NBS) 2005, China Statistical Yearbook 2005, China Statistics Press, Beijing.

\section{General implications}

If we combine the preceding observations from the competitive market and the strategic market, we can see how SOE reforms have left the government fundamentally better off. In the competitive market, the number of lessefficient and less-profitable SOEs was dramatically reduced, while in the strategic market SOEs were guarded and profits soared. At the same time, this course of reforms has significant wider implications.

\section{Impact on NSEs: infrastructural support and price controls}

SOE reforms have successfully created room for non-state enterprises (NSEs) to grow. Assets in NSEs have soared from RMB1264.6 billion in 1995 to RMB11 545.8 billion in 2005, with profit rising from RMB58.2 billion in 1995 to RMB812.6 billion in 2005 (Table 9.14).

The dominance of SOEs in China's strategic market has contributed to this success in two distinct ways. On the one hand, SOEs still hold state monopolies over critical sectors such as infrastructure. By centrally coordinating and pursuing its efforts in these regards, the Chinese Government has managed to provide an extensive and ever-growing infrastructure network as one of the pillars of overall economic growth. 


\section{Table 9.14 Performance of NSEs in large and medium-sized industrial enterprises}

\begin{tabular}{lccc}
\hline Year & Assets (RMB billion) & Profit (RMB billion) & ROA (\%) \\
\hline 1995 & 1264.6 & 58.2 & 4.60 \\
\hline 2000 & 3584.2 & 224.4 & 6.26 \\
\hline 2005 & 11545.8 & 812.6 & 7.04 \\
\hline
\end{tabular}

$\mathrm{ROA}=$ return on assets

Sources: National Bureau of Statistics (NBS) 1995, China Statistical Yearbook 1995, China Statistics Press, Beijing; National Bureau of Statistics (NBS) 2000, China Statistical Yearbook 2000, China Statistics Press, Beijing; National Bureau of Statistics (NBS) 2005, China Statistical Yearbook 2005, China Statistics Press, Beijing.

The growth in infrastructure is outstanding: in the area of transportation routes, the length of railways in operation extended from 59700 kilometres in 1995 to 77 100km in 2006 (up 28 per cent). The length of highways extended from 1.16 million km in 1995 to 3.46 million in 2006 (up 200 per cent) and the length of civil aviation routes extended from 1.13 million km in 1995 to about 2.11 million $\mathrm{km}$ in 2006 (up 87 per cent). Postal delivery routes, which were about 1.9 million $\mathrm{km}$ in length in 1995, extended to 3.4 million $\mathrm{km}$ at the end of 2006 (up 79 per cent). As for telecommunications, the capacity of mobile telephone exchanges extended from 8 million subscribers in 1995 to 610 million subscribers in 2006 (up 7525 per cent), and broadband subscriber ports extended from 18 million ports in 2003 to 65 million ports in 2006 (up 260 per cent) (see Appendices 9.4-7 for details on infrastructure growth).

Another channel through which the dominant position of SOEs in the strategic market has contributed to NSE growth is by upholding price controls. Since SOEs still hold monopolies in these strategically relevant sectors, the prices of energy, water and resources are kept artificially low. On the one hand, this serves Chinese consumers. On the other, private and other nonstate enterprises also benefit notably from this favourable price environment.

The implicit subsidisation of the private sector, however-including many foreign-invested enterprises - through lower than market prices in key inputs implies that China is subsidising global consumers of madein-China products. It has also attracted many energy-intensive and environmentally harmful industrial activities to China. On the whole, the price controls that followed from the tight control by the government of SOEs in the strategic market have led to significant hidden social costs. It will be interesting to see how long China can sustain the price control and the implicit subsidies to domestic and international firms and consumers. 


\section{Distorted distribution of wealth}

SOE transformation has so far increased state-owned assets and profits. The resulting wealth distribution seems unbalanced, as state-owned assets are centralised within the strategic market. While about 51 per cent of all SOEs are included in the strategic market, the assets accumulated here amount to RMB4664 billion, or 77 per cent of total state-owned assets in large and medium-sized industrial enterprises. At the same time, profit generated from SOEs in the strategic market amounts to RMB24l billion, which equals 90 per cent of the total profit generated from large and medium-sized SOEs (Table 9.15).

\section{Table 9.15 Structure and performance of SOEs in strategic and competitive markets, 2005 (per cent)}

\begin{tabular}{lccc}
\hline & Total & Strategic market & Competitive market \\
\hline No. SOEs & 100 & 51.61 & 49.39 \\
Assets & 100 & 76.62 & 23.38 \\
Profit & 100 & 89.97 & 10.03 \\
\hline
\end{tabular}

Source: National Bureau of Statistics (NBS) 2005, China Statistical Yearbook 2005, China Statistics Press, Beijing.

The centralisation of assets and profits in the strategic market and the strengthened monopoly position of SOEs in the most profitable sectors of the Chinese economy, as well as the low efficiency and low productivity of SOEs, all indicate a distorted allocation of wealth. This is prone to hinder innovation and entrepreneurship in China's largest companies and most important sectors, as well as encumbering enterprise efficiency and industrial productivity.

\section{Impact on China's consumption and savings}

Retaining profitable SOEs in the strategic market also has major implications for China's macroeconomic balance. Since SOE dividends are not paid out to shareholders, a major source of wealth and income is held back. As a result, household consumption is about only 37 per cent of GDP and household income is about 45 per cent of national income (Table 9.16). High savings held by SOEs and the government (through high taxation) are among the key reasons for China's low consumption rate and large current account surplus. 
Table 9.16 China's household income and consumption, 2007

\begin{tabular}{lcc}
\hline & (RMB billion) & Percentage of GDP (\%) \\
\hline Household income & 11198 & 45 \\
\hline Household consumption & 9332 & 37 \\
\hline
\end{tabular}

Note: Household income is estimated using data on per capita income of rural and urban households multiplied by the respective population estimates.

Source: National Bureau of Statistics (NBS) 2008, China Statistical Yearbook 2008, China Statistics Press, Beijing.

\section{Concentration of SOEs among top-500 Chinese companies}

After several stages of reform, Chinese SOEs still dominate among large enterprises in China to a remarkable degree. SOEs account for 70 per cent of the Chinese top-500 enterprises, 94 per cent of assets and 88 per cent of profits. The Chinese SOEs also contribute 93 per cent of the taxes generated from, and employ 89 per cent of the total workforce in the Chinese top500 enterprises (Table 9.2). Although the Chinese SOEs perform worse than non-state enterprises such as collective-owned enterprises, privateowned enterprises and foreign-funded enterprises, they still dominate among large manufacturing enterprises. In the manufacturing sector, SOEs account for about 50 per cent of firms, contributing 61 per cent of the total profit generated from the top-500 Chinese manufacturing enterprises (Table 9.3). In the service sector, SOEs account for 61 per cent of firms, 93 per cent of assets and 92 per cent of profits among the top-500 Chinese enterprises in the service industry (Table 9.4).

Even globally, Chinese SOEs are becoming more and more significant. The number of Chinese enterprises in the Fortune Global 500 increased from 15 in 2005 to 22 in 2007 and China ranked sixth in 2007 in the number of firms by country (Table 9.17).

\section{Table 9.17 The number of Chinese enterprises in the Fortune Global 500}

\begin{tabular}{ll}
\hline Year & No. of Chinese enterprises \\
\hline 2005 & 15 \\
\hline 2006 & 19 \\
\hline 2007 & 22 \\
\hline
\end{tabular}

Note: All of the Chinese enterprises in the Fortune Global 500 are SOEs.

Source: 'Fortune Global 500', Fortune Magazine, 23 July 2007. 


\section{Some policy implications}

To address the apparent shortcomings of past SOE reforms, we propose full privatisation as part of a large-scale reform of China's financial sector. ${ }^{1}$ Reforms should focus on limiting the role of the State and increasing the global competitiveness of Chinese enterprises. We present several recommendations for such a scenario:

- all large SOEs under central or local-government control should be listed within a short period - that is, five to 10 years

- for SOEs that are already listed, state ownership should be reduced to a minority shareholder level — for example, below 30 per cent — within three to five years

- state-owned shares should be limited to less than 50 per cent for all new initial public offerings (IPOs)

- listed SOEs should be required to have a plan to further reduce state ownership - for example, to below 30 per cent - within three to five years after their IPO.

Majority state ownership is neither necessary to represent the interests of the State nor advantageous in improving the competitiveness of the listed company. The interest of the State can still be maintained through one golden share that gives the State veto power against any decisions by the board that are potentially harmful to the national interest or national security.

\section{Summary and conclusion}

By using various statistical data, this chapter examines the transformation of SOEs during the reform period from 1995 to 2005, which has been characterised on the one hand by a sharp decline in the number of firms and on the other hand by a steady accumulation of state-owned assets. The results of this study show that it is the competitive market where there is a sharp decline in the number of SOEs and the strategic market where there is a steady accumulation of state-owned assets. We have shown how Chinese SOEs are more likely to be privatised when they are losing profit. When they are more profitable, their sector's monopoly position is more likely to be strengthened, which leads us to the conclusion that the privatisation of SOEs in China has been driven by an implicit objective of the government to maximise financial, social and political assets and minimise financial, social and political liabilities. 
Moreover, we point out that this specific course of reform has affected China's macroeconomic environment in a number of ways. NSEs have benefited from the continuing monopoly position of SOEs in the strategic market in the sense that they can take advantage of a vast system of basic infrastructure, as well as of lasting price controls on energy and resources. The over-concentration of SOEs in the strategic market seems to have served specific government purposes to bolster the nation's economic growth. Low efficiency and productivity in these sectors still hinder innovation and entrepreneurship in China's largest companies and in China's most important sectors. Apart from this domestic problem of a distorted distribution of wealth, the global impacts of the ever-growing Chinese SOEs will not be ignored abroad. Therefore, there will be a further demand for transformation of the Chinese SOEs with pressure coming from domestic consumers and politics, as well as from international competition and international politics.

\section{References}

A Report on the Development of China's Enterprises 2007, Enterprise Management Publishing House, Beijing.

'Fortune Global 500', Fortune Magazine, 23 July 2007.

National Bureau of Statistics (NBS) 1995, China Statistical Yearbook 1995, China Statistics Press, Beijing.

2000, China Statistical Yearbook 2000, China Statistics Press, Beijing.

2005, China Statistical Yearbook 2005, China Statistics Press, Beijing.

_2008, China Statistical Yearbook 2008, China Statistics Press, Beijing.

Ten policy recommendations to build Shanghai into a top international financial center within a decade, Brookings-Tsinghua Center Working Paper, Brookings-Tsinghua Center, Beijing.

\section{Endnotes}

1. See Ten policy recommendations to build Shanghai into a top international financial center within a decade, Brookings-Tsinghua Center Working Paper, Brookings-Tsinghua Center, Beijing. 


\section{Appendix 9.1 List of industry codes and the full industry name}

06 Coal mining and dressing (CMD)

07 Petroleum and natural gas extraction (PNGE)

08 Ferrous metals mining and dressing (FMMD)

09 Non-ferrous metals mining and dressing (NFMMD)

10 Non-metal minerals mining and dressing (NMMD)

13 Food processing (FPc)

14 Food production (FPd)

15 Beverage production (BP)

16 Tobacco processing (TP)

17 Textile industry (TI)

18 Garments and other fibre products (GOFP)

19 Leather, furs, down and related products (LFDRP)

20 Timber, bamboo, cane, palm fibre and straw (TBCPFS)

21 Furniture manufacturing (FM)

22 Papermaking and paper products (PPP)

23 Printing and recording medium reproduction (PRMR)

24 Cultural, educational and sporting goods (CESG)

25 Petroleum processing and coking (PPC)

26 Raw chemical materials and chemicals (RCMC)

27 Medical and pharmaceutical products (MPP)

28 Chemical fibre (CF)

29 Rubber products (RP)

30 Plastic products (PP)

31 Non-metal mineral products (NMP)

32 Smelting and pressing of ferrous metals (SPFM)

33 Smelting and pressing of non-ferrous metals (SPNFM) 
34 Metal products (MP)

35 Ordinary machinery manufacturing (OMM)

36 Special purposes equipment manufacturing (SPEM)

37 Transport equipment manufacturing (TEM)

39 Electric equipment and machinery (EEM)

40 Electronic and telecommunications equipment (ETE)

41 Apparatus and instruments (AI)

42 Cultural, office machinery and other manufacturing (COMOM)

43 Recycling industry (RI)

44 Electric power, steam and hot water (EPSHW)

45 Gas production and supply (GPS)

46 Tap water production and supply (TWPS) 


\section{Appendix 9.2 List of sectors in the strategic market}

06 Coal mining and dressing (CMD)

07 Petroleum and natural gas extraction (PNGE)

08 Ferrous metals mining and dressing (FMMD)

09 Non-ferrous metals mining and dressing (NFMMD)

10 Non-metal minerals mining and dressing (NMMD)

16 Tobacco processing (TP)

25 Petroleum processing and coking (PPC)

27 Medical and pharmaceutical products (MPP)

32 Smelting and pressing of ferrous metals (SPFM)

33 Smelting and pressing of non-ferrous metals (SPNFM)

44 Electric power, steam and hot water (EPSHW)

45 Gas production and supply (GPS)

46 Tap water production and supply (TWPS) 


\section{Appendix 9.3 List of sectors in the competitive market}

13 Food processing (FPc)

14 Food production (FPd)

15 Beverage production (BP)

17 Textile industry (TI)

18 Garments and other fibre products (GOFP)

19 Leather, furs, down and related products (LFDRP)

20 Timber, bamboo, cane, palm fibre and straw (TBCPFS)

21 Furniture manufacturing (FM)

22 Papermaking and paper products (PPP)

23 Printing and recording medium reproduction (PRMR)

24 Cultural, educational and sporting goods (CESG)

26 Raw chemical materials and chemicals (RCMC)

28 Chemical fibre (CF)

29 Rubber products (RP)

30 Plastic products (PP)

31 Non-metal mineral products (NMP)

34 Metal products (MP)

35 Ordinary machinery manufacturing (OMM)

36 Special purposes equipment manufacturing (SPEM)

37 Transport equipment manufacturing (TEM)

39 Electric equipment and machinery (EEM)

40 Electronic and telecommunications equipment (ETE)

41 Apparatus and instruments (AI)

42 Cultural, office machinery and other manufacturing (COMOM)

43 Recycling industry (RI) 


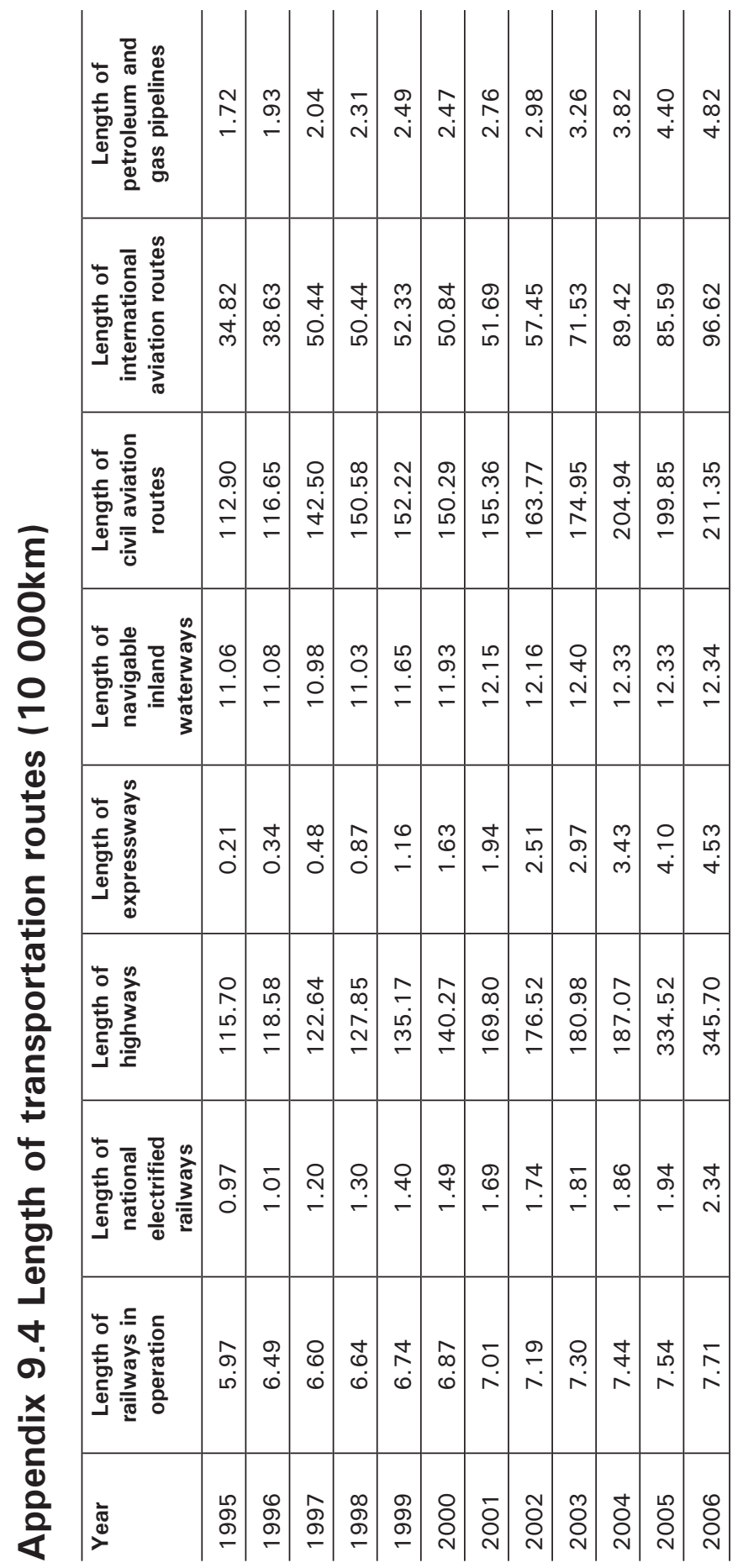




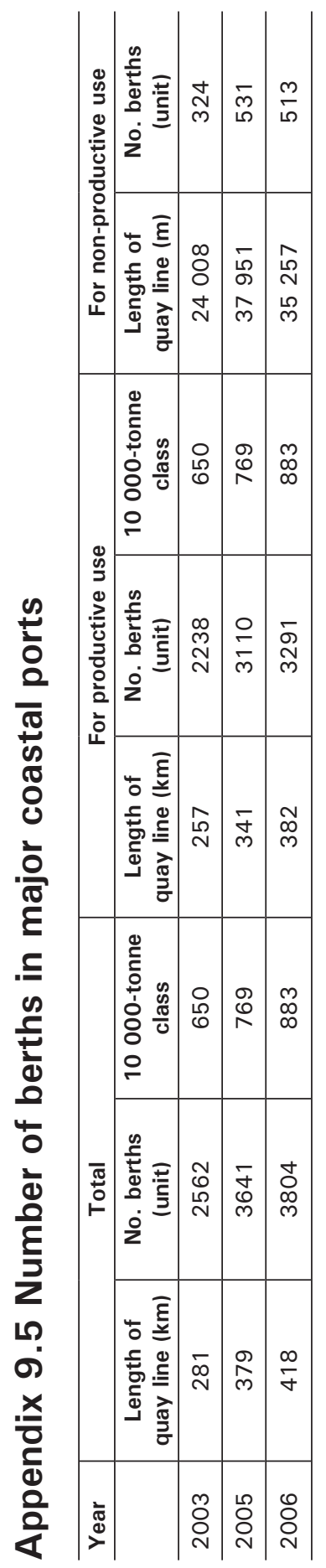




\section{Appendix 9.6 Postal delivery routes}

\begin{tabular}{l|c|c|c}
\hline $\begin{array}{l}\text { ('000 km) } \\
\text { Year }\end{array}$ & Length of postal routes & Highway routes & Railway routes \\
\hline 1995 & 1886 & 819 & 183 \\
\hline 1996 & 2119 & 917 & 184 \\
\hline 1997 & 2363 & 874 & 186 \\
\hline 1998 & 2854 & 931 & 190 \\
\hline 1999 & 2979 & 989 & 190 \\
\hline 2000 & 3073 & 1070 & 185 \\
\hline 2001 & 3103 & 1074 & 180 \\
\hline 2002 & 3081 & 1113 & 178 \\
\hline 2003 & 3270 & 1137 & 191 \\
\hline 2004 & 3336 & 1195 & 196 \\
\hline 2005 & 3406 & 1230 & 200 \\
\hline 2006 & 3369 & 1231 & 205 \\
\hline
\end{tabular}




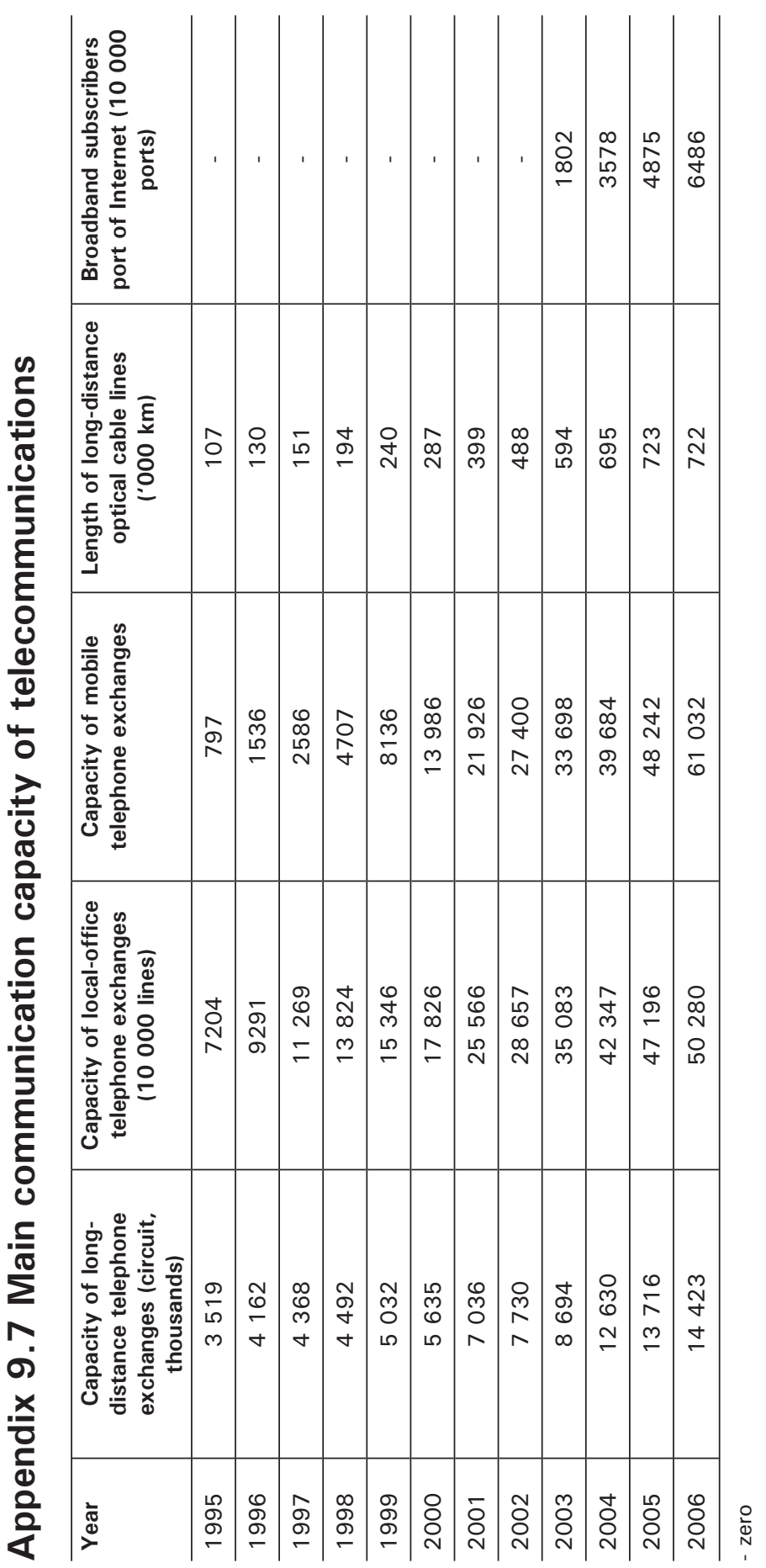

